\author{
Nawal A Al-Fattah \\ Taif University, Saudi Arabia
}

\title{
MULTILINGUALISM AND IMAGES OF THE OTHER: FROM CONFLICT BETWEEN NATIONS TO DIALOGUE OF CIVILIZATIONS
}

\begin{abstract}
Summary. In this era of war of words, multiple language acquisition and cultural awareness can be tools to end misunderstanding and conflicts between civilizations. Language barriers lead to poor communication, and establishing a multilingual society can eradicate misunderstanding stemming from lack of proficiency in one another's languages and ways of thinking. This study investigates in detail the benefits of multilingualism for civilizational dialogue, and focuses on the importance of utilizing mass media to foster such communication. It addresses the relationship between multilingualism and constructive dialogue, proving that multilingualism is not a "problem" to be "solved." Some historical and contemporary examples of the importance of language in civilizational dialogue have been introduced to prove the positive effects of multilingualism. These examples show how mastering more languages might have a positive impact on societies. Also, a total of 159 participants speaking more than one language were administered a questionnaire. The majority of participants agreed that multilingualism promotes civilizational dialogue more than monolingualism does. They agreed that political and religious clashes stem from cultural differences in the understanding of some words.
\end{abstract}

Keywords: civilization, conflict, dialogue, global, multilingualism.

\section{Introduction}

Although the World Wide Web has brought people together, many people around the world continue to hold stereotyped or prejudicial views about each other on political, religious, social, and economic issues, at both micro and macro levels. This paper argues that one way to resolve the social issues attendant on this situation is a global focus on multiple language acquisition, which has become more and more important in recent decades with the advancement of a global economy, media, and etc. Globalization forces us to expand our foreign language ability, because crosslinguistic communication plays a pivotal role in global dialogue.

Globally, multilingualism is considered to be the rule, not the exception. Edwards (1994, p. 1) argues:

To be bilingual or multilingual is not the aberration supposed by many (particularly, perhaps, by people in Europe and North America who speak a "big" 
language); it is rather a normal and unremarkable necessity for the majority in the world today.

Monolingual people (especially those monolingual in languages other than English) may find many doors of communication closed to them and their ability to engage in dialogue restricted. For example, there has been substantial growth in internet usage in recent years, enabling people from many linguistic backgrounds to communicate to a new and larger international audience in their own language; however; a monolingual society cannot reach out to the rest of the world, because of the language barriers that persist. Orban, the former Commissioner for Multilingualism in the European Commission, mentions that only $2 \%$ of Europeans live and work outside their country, and says that the EC surveys show that workers and their families consider lack of language skills to be the main obstacle to moving abroad in search of new opportunities (Orban, 2008, p. 4).

Multilingualism changes all this. Being multilingual means that you become a world citizen who has the ability to communicate with the rest of the world and can engage in civilizational dialogue at all levels. As the late Nelson Mandela said, "[I]f you talk to a man in a language he understands, that goes to his head. If you talk to him in his language that goes to his heart." We live in an era in which the world is in need of civilizational dialogue to bring people together and solve pressing problems: a means of communication is needed to overcome the obstacles that may lead to political, cultural, and religious misunderstanding. According to Cenoz (1998, p. vii), "There is a growing need of individual multilingualism as a result of increasing communications among different parts of the world and the need to be competent in languages of wider communication." Communicative proficiency in two or more languages can act as a bridge between cultures and a tool for civilizational dialogue. It can help achieve sincere communication with others and cultivate common ground among people all over the world.

In short, dialogue is the heart of peace; and to open the locked door of dialogue, we need the key of language. Multiple language acquisition and developing linguistic awareness enable us to perceive that the real power of 
language lies in its ability to foster active and civilizational dialogue-dialogue always rooted in intercultural understanding. Multiple language acquisition does not provide us with knowledge alone, but also with global communities and a global citizenry, working together in a positive spirit.

In recent years, there has been an increased awareness of the need to multilingualism. Tokuhama-Espinosa (2008) has explored the benefits of multilingualism and has exhorted parents and teachers to extend multilingual learning across the lifespan. She writes,

[t]oday languages are highly valued around the world by a myriad of professions, something that marks a turning point in human linguistic endeavors. Never before in the history of the world have so many people been literate in multiple languages. Never before has the demand for people who speak other languages and have a window into other cultures been so high.

Never before has there been so great a need to improve communication between different countries, businesses, and individuals as there is today. (p. 10)

One potential way of fueling dialogue, as outlined above, is learning multiple foreign languages. Many studies of multilingualism have been done; however, most of them concentrate on language acquisition and multilingual education. As Kneucker and Crepaz (2009) argue, "[i]f the EU can manage to prove to its citizens that the acquirement of additional languages may be the key to making a difference in the future, multilingualism and cultural understanding in Europe will surely be fostered" (p. 12). Others see multilingualism more explicitly as a problem that requires a solution; as Blommaert and Spotti (2012) argue, "Multilingualism proves problematic also in everyday informal, interactive web discussion forums" (p. 14).

This study will focus primarily on the impact of learning multiple foreign languages and will argue that this is the only effective means of civilizational communication. In that connection, the study aims to show how multiple language acquisition enhances international and intercultural communication. It investigates the conflicts and clashes among civilizations that result from lack of dialogue. A 10-question survey was administered to a group of multilingual respondents to measure their opinions about the importance of multiple language 
acquisition in achieving global understanding and intercultural communication. The results support the argument that the problem of clash of civilizations can be solved through multilingualism, in that the majority of the participants who know more than one language agreed that multilingualism promotes civilizational dialogue more than monolingualism does.

First, below, the study sets out some goals and gives some historical and contemporary examples of the importance of languages in civilizational dialogue. Next, it explores the importance of multiple language acquisition in achieving global inter-intelligibility and communication and understanding the world from different perspectives. Finally, the survey methodology is explained and the results presented and discussed.

\section{Goals of the Study}

- To prove that multilingualism is not a problem to be solved, but a solution to religious, political, social, and economic clashes;

- To address the relationship between multilingualism and intercivilizational dialogue; and

- To state that civilizational dialogue, mutual understanding, and communication opportunities can be created by proficiency in more than one language.

\section{Conceptual Background}

Multilingualism, according to Clyne (2007), refers to "either the language use or the competence of an individual, or to the language situation in an entire nation or society" (p. 301). Stolarickô and Florida (2006) have observed that multilingualism helps us understand the world from different perspectives and makes us more likely to devise creative and innovative solutions: it is "good for the brain to have to learn how to work and think in [multiple languages]" (p. 1812). These researchers define multilingualism according to their different purposes, but the common point is as Kachru (1989) describes it: multilingualism is the "linguistic behavior of the members of a speech community which 
alternately uses two, three or more languages depending on the situation and function" (p. 159).

Some linguists argue that multilingualism is a problem, whether in international relations (Buda, 2010) or in everyday contexts (Blommaert \& Spotti, 2012). It is argued that

[s]peaking another language than the "national" one, when seen from within the ethnolinguistic assumption, creates a fundamental problem of otherness for which a range of solutions was designed, from extinction and expulsion over assimilation to integrationbecause a "normal" person naturally belongs to only one language and culture unit (Blommaert \& Spotti, 2012, p. 4).

Thus, they add, even if multilingualism is in general and in principle a positive thing, it can in actual fact be a problem for individuals and social groups (p. 2). Likewise, Kytölä (2013) shows how multilingualism can be problematic in web discussion forums. He thinks that sociolinguistic diversity leads to "more misunderstanding and potential conflict online," (p. 164) and adds that multilingual action is a "hindrance to certain desired social trajectories as well as a cause of mockery and degradation" (p. 164).

Nevertheless, international organizations such as UNESCO continue to valorize multilingualism for promoting social cohesion and intercultural dialogue. According to the UNESCO World Report (2009), "multilingualism and translation have necessary and complementary roles in the promotion of intercultural dialogue. Multilingualism fulfills the dual function of facilitating communication between individuals of different cultures and contributing to the survival of endangered languages" (p. 80).

The present study argues that multilingualism is a solution rather than a problem and that it should ideally lead to mutual understanding rather than problems. This is a position with its own research pedigree. For instance, Ngubane (2003, par. 25), speaking in the South African context, assures us that "multilingualism [...] will afford individuals great opportunities. Opportunities to make choices, opportunities to be empowered and opportunities to be educated." De Angelis and Dewaele (2009) argue that "in the 1960s, it was difficult to speak about bilingualism or multilingualism in a constructive manner, as most 
researchers were convinced that the knowledge of non-native languages was a hindrance rather than an asset for the individual" (p. 65).

Peal and Lambert (1962) discuss the advantages of multilingualism in terms of cognitive flexibility in comparison to monolingualism. According to Orban (2007), "the ability to communicate in several languages is a great benefit for individuals, organizations and companies. It enhances creativity, breaks cultural stereotypes, encourages thinking 'outside the box', and can help develop innovative products and services." From this perspective, we need multilingualism as a communicative tool in this time of globalization. Orban (2008, p. 4) states that "By learning languages, and gaining an insight into the point of view of others, we become more tolerant, more ready to compromise, more conscious of the complexity of our society. ${ }^{3}$ We learn to see our many mother tongues as a source of wealth and a pathway to greater solidarity and mutual understanding." He also emphasized the importance of multilingualism in uniting Europeans:

Multilingualism has shaped the European project from the very start. Just over 50 years ago, old enemies came together to build the Union on the ashes of their former conflicts. The fact that they put the languages of the founding states on an equal footing was not empty symbolism. It was a real commitment to the dialogue which underpins Europe (Orban, 2009, p. 2).

Thus, in the present study, we intend to show that multilingualism enhances intercultural dialogue and solves the problem of conflict between nations.

\section{Proficiency in Foreign Languages as a Tool for Facing Global Conflicts}

Multilingual media can serve as a bridge between people all over the world and promote mutual understanding among them. With the establishment of foreign language universities which focus on research and language teaching to develop proficiency in foreign languages, we can develop a population that is linguistically and culturally equipped to communicate successfully. Multilingual people can understand and tackle political and religious disputes in different ways according to their different linguistic and cultural backgrounds, making them better able to find solutions. For example, political and religious clashes rest on and are structured by cultural differences through the understanding of words like jihad, 
terrorism, peace, democracy, liberty, and so on, which are highly language specific. As Kymlicka (2001) has said,

Democratic politics is politics in the vernacular. The average citizen feels at ease only when he discusses political questions in his own language. As a general rule, only elites are fluent in more than one language and have the chance to maintain and develop their linguistic skills continuously and feel at ease discussing political questions in different languages in a multilingual atmosphere. (p. 213)

Thus, a shared language is crucial to facilitating open dialogue to allow people to discuss and learn more about the histories, politics, and cultures of other peoples. Hence, the ability to speak to others in their own language can help in understanding political developments and counteracting stereotyped views.

Let us reconsider the list of words above. It is important to clarify the meanings of these words-especially those which are originally Arabic and do not have semantic equivalents in other languages, because some of the greatest misconceptions causing conflict in the world today concern Arabic concepts such as Islam and jihad. Unless these words are understood in cultural context, it is impossible to fully grasp their layers of meaning. The ability to use several languages with good awareness of linguistic and semantic context and diversity can narrow the gap between an intended meaning and an understood meaning and lead to the removal of barriers to dialogue between civilizations. It helps an interlocutor to grasp nuances of meaning and social implications behind the overt meanings of words. What closes avenues for dialogue with others, in contrast, is low competence in their languages.

From the point of view of cognitive linguistics, understanding the meaning of the key word (KW) depends heavily on the knowledge base of the language users. People who are equipped with better linguistic and extra linguistic knowledge are more efficient to understand the contextual meaning of the $\mathrm{KW}$ than others. (Dash, 2008, p. 29) In fact, we need to train and prepare linguists to attain advanced foreign language proficiency to clarify distorted terms and ensure effective and productive communication. For example, with multilingual TV channels, we can reach the entire world. Further, we can become a superpower that has a dominant position by having the power of languages instead of the 
power of military forces. With the power of languages, we can exert our sovereignty and have a tremendous impact on others through better communication and thus better relations. Although the United States is the world's military superpower, it lacks strong foreign language proficiency. The Committee for Economic Development (CED, 2006) has commented that "[d]espite America's status as an economic, military and cultural superpower, we risk becoming narrowly confined within our own borders, lacking the understanding of the world around us that is essential to our continued leadership role in the world community" (p. vii). This indicates the importance of multilingualism in the leadership of countries and the fact that a lack of multilingualism leads to a lack of understanding of the world.

Over time, our effectiveness in communicating America's message to the world could be decisive in encouraging countries throughout the Middle East and South Asia to embrace democratic pluralism and reject violent extremism. To make our case persuasively, we will need credible, articulate representatives who have attained a high degree of proficiency in a host of strategic languages and dialects as well as an understanding of the cultures and geographic contexts of these regions. (CED, 2006, p. 8)

The September $11^{\text {th }}$ intelligence failures provide considerable evidence of our shortage of expertise in Arabic and Asian languages and cultures. The Army, for example, had authorization for 329 translator and interpreter positions for its five critical languages (Arabic, Korean, Mandarin Chinese, Persian/Farsi, and Russian) in fiscal year 2001, but was able to fill only 183 of them, a shortfall of 44 percent. (CED, 2006, p. 9)

From the above quotes, we recognize the crucial importance of a good grasp of languages and see how the awareness of multilingualism's importance has increased. Lack of shared language is obstructive to communication and mutual understanding. The consequence of the lack of foreign language skills is the failure of religious, political, social, and economic dialogue.

Societies depend on the individuals making them up. If societies contain many multilingual individuals who can communicate with people all over the world religiously, politically, socially, and economically, this will lead to dialogue between governments and civilizations. Learning languages is central to the development of a better society, and societies where many people master many 
languages will have a powerful tool for building stronger and more productive communication with the whole world. Orban (2008) says, "The Commission believes that multilingualism should serve the citizen: languages should be for all and not just for the élite. Professionals with language skills and trained interpreters help the institutions of multilingual societies to function."

Multilingualism can be a national responsibility for reasons other than those of international politics. It is a religious necessity in the Kingdom of Saudi Arabia, an Islamic country visited by millions of people from all over the world who come to perform the Hajj, the pilgrimage to Mecca required of every Muslim. The Saudi government would do well to put more emphasis on multiple language acquisition and cultural literacy, because these pilgrims speak multiple languages and come from many cultural backgrounds. Thence, multilingualism becomes also a religious necessity for Saudis:

- To enhance dialogue with pilgrims and help them feel comfortable and communicate without translators;

- To help pilgrims overcome their feelings of isolation and promote positive intercultural interaction;

- To create an environment that expresses respect for all pilgrims, regardless of their racial, ethnic, or cultural background; and

- To help scouters guide pilgrims and communicate effectively with them to meet their needs.

In short, lack of foreign language proficiency is a stumbling block to productive communication. According to Mandujano (2008), the executive director of the Enterprise Center Community Development Corporation, "When you know the language of the clients you are serving, you get to talk to people in the language that they are most comfortable in. And people open up a lot more when they are comfortable" (as cited in Hulstrand, 2008, p. 28).

Language education structures need to be reconsidered in many countries if they are to meet the challenges of globalization. Programs are needed to strengthen education in foreign languages, and students should be required to have proficiency in at least two or three languages. To accomplish this, the 
students themselves must recognize the importance of foreign languages for effective communication.

Multilingualism will also be important for societies to communicate with foreigners inside their borders. Multilingual citizens have the ability to think and communicate globally in different realms, such as mass media, international trade, international relations, and computer technologies. (See Fig. 1.)

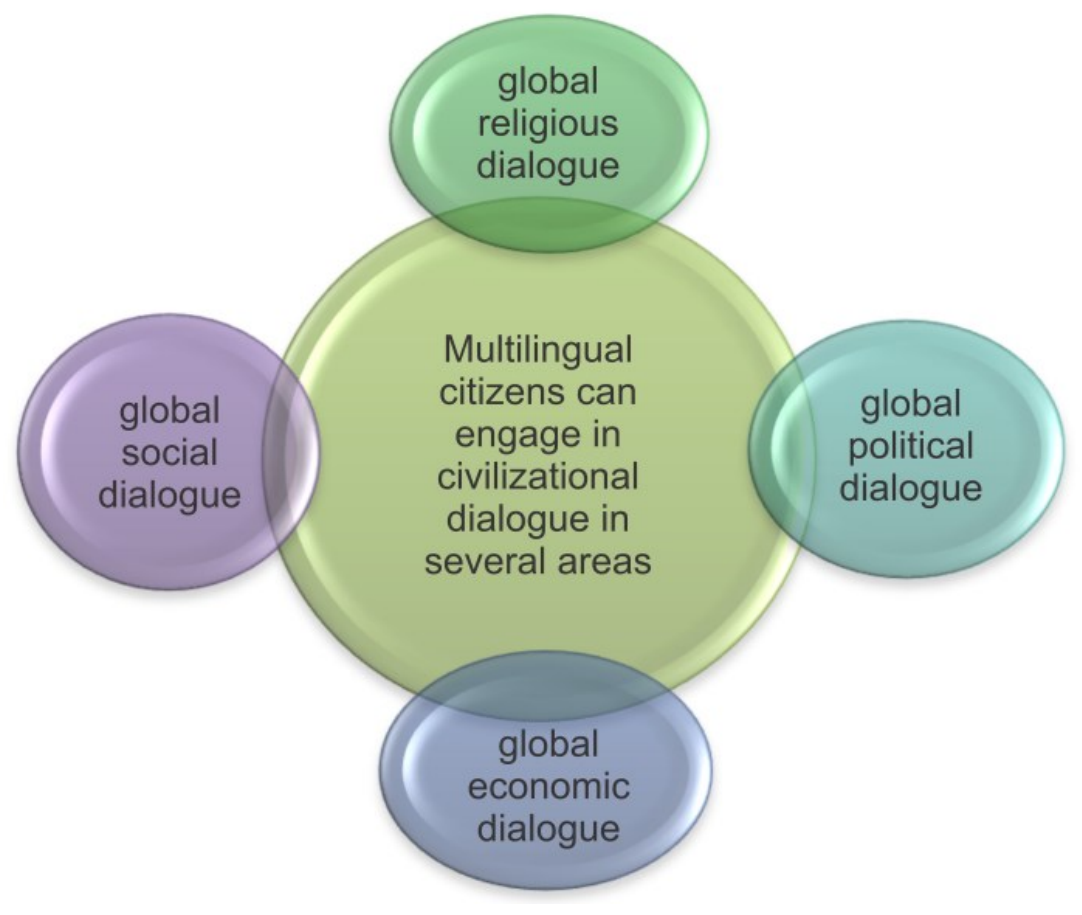

Fig. 1. Areas of civilizational dialogue

Thus, a multilingual society is unique for having linguistic wealth that boosts communicative competency. Thinking of society in terms of a pyramid, we can understand a "multilingual society" at the present time to exist only at the top of the pyramid, among the elite. Conversely, the vast majority of the world, or the base of the pyramid, are monolingual, lacking linguistic as well as economic wealth. Thus, the more languages a society knows, the higher it is on the pyramid of societies (See Fig. 2.) 


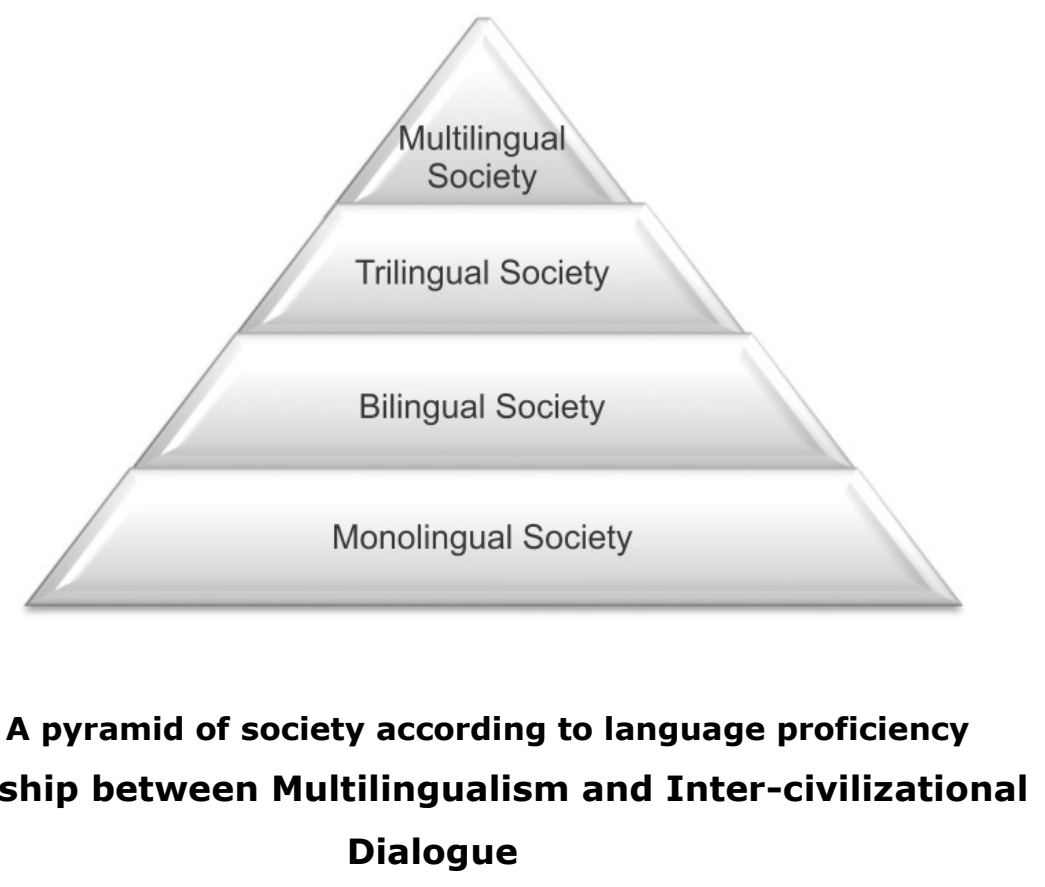

Fig. 2. A pyramid of society according to language proficiency

\section{Relationship between Multilingualism and Inter-civilizational Dialogue}

According to Bakar (2001), inter-civilizational dialogue means "a conversation between different civilizations on fundamental and vital issues that confront contemporary man, as well as on perennial issues which arise from the very nature of man and his existence, both individual and societal or collective" (pp. 165-166). We are living in a world suffering from a war of words resulting from misunderstanding of each other's real meanings. Abu Bakr (2004) states:

The relationship between Arab and Western intellectual elites is distorted, representing a major obstacle on the path to reaching a mutual understanding, where both sides would benefit. Many "revolutionist" intellectuals in [Arab] countries retreat from facing this obstacle, instead waging a daily war of words on Arab satellite TV stations, against American policy in the Middle East. This only expands the prevailing valley of misunderstanding.

Stereotypes and blunders result from a low level of knowledge about languages and cultures; conversely, learning languages enables us to understand the meaning of ideas expressed in those languages on a deeper level and therefore to avoid falling prey to the distorted representations in the media. Lack of language 
proficiency does not only imply difficulties of communication, but can extend to clash of civilizations. (See Fig. 3.)

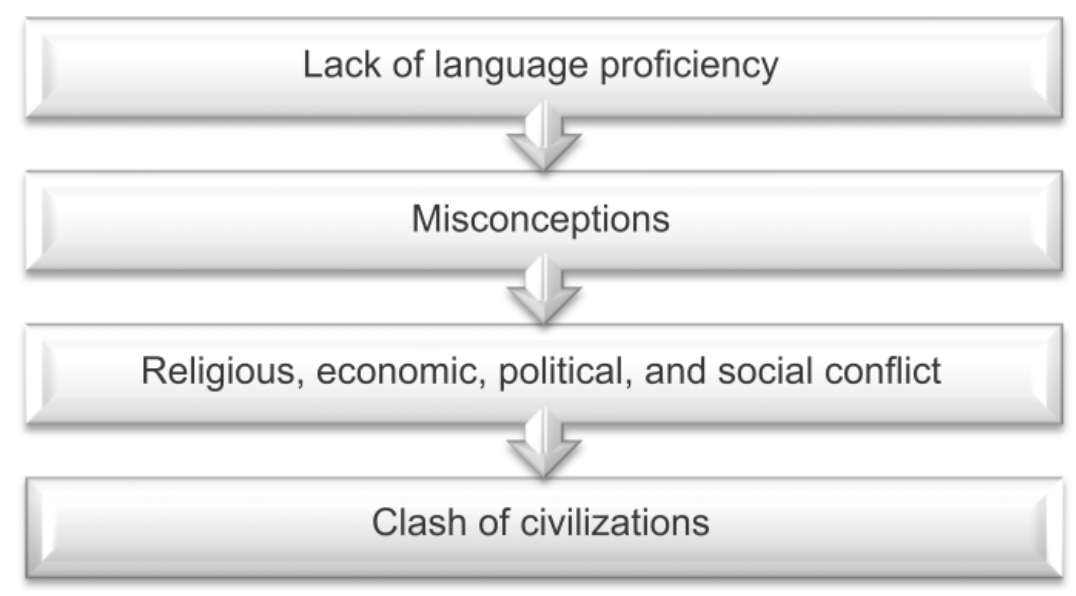

Fig. 3. The stages of clash of civilization

To change this clash of civilizations into dialogue of civilizations, we have to dispel the misconceptions regarding words that prevail in the media. As Afroz (2004) has pointed out, "[I]anguage is MHT ... a massive human tool, and probably more powerful than weapons, in both directions of the scale ... benefit or harm. Today, more so than ever, words are a weapon of choice as WMD-words for mass delusion." (p. 1).

Scarino and Crichton (2007) state, "[I]anguages have a central role in this context of globalization because they mediate the interpretation and construction of meaning among people" (p. 3). In fact, a lot of Arabic and Islamic political and religious terms have had their real meanings subverted in the Western media as a result to some degree of lack of sufficient knowledge of foreign languages. One excellent example is jihad, or "struggle," a concept that might have been distorted and associated with terrorism because the Western media lacks deep knowledge of foreign languages and cultures. It signifies the exertion of one's power in the form of struggle against evil for the sake of Allah.

The CED (2006) has pointed out the US's major need for foreign language skills: 
The FBI and other federal government agencies lack sufficient linguists to translate intelligence information in critical languages in a timely manner. Furthermore, our diplomatic efforts often have been hampered by a lack of cultural awareness. President George W. Bush has encouraged Americans to learn the languages and cultures of the Middle East, and in early 2006 introduced the National Security Language Initiative to increase the number of Americans with advanced proficiency in critical languages. (p. 2)

It is clear from the above statements that America suffers from linguistic shortcomings and that many foreign-language concepts have lost their real meaning in US media because of a lack of language proficiency. Therefore, we need to strengthen our education system to provide students of language with better opportunities for learning. We also need to improve our media coverage, religiously, socially, economically, and politically, in various languages. Through multilingual media, we can promote understanding of misconceptions, overcome misunderstandings, and stop the war of words that threatens world peace. The world has become more and more open and people can reach each other much more easily; global and civilizational dialogue needs to be built on the two pillars of skills in foreign languages and cultural competence, which do not necessarily coincide (Fig. 4).

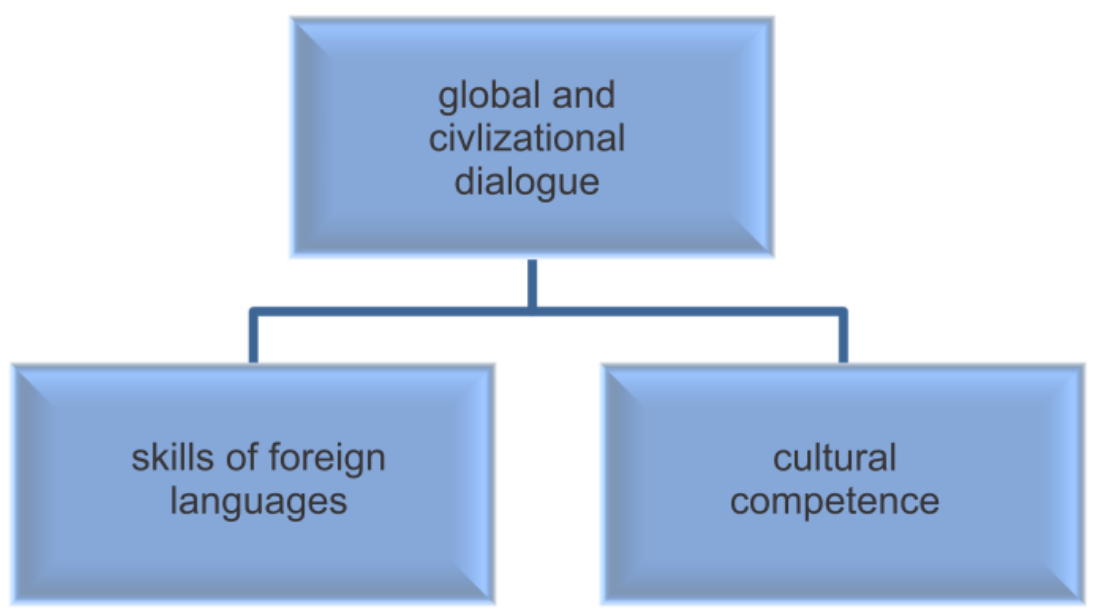

Fig. 4. Pillars of global and civilizational dialogue 
To sum up, cultural competence and knowledge of foreign languages are the prerequisites for building civilizational dialogue and mutual understanding. Multiple language acquisition also enhances global business through global economic dialogue, which increases mutual respect, mutual understanding, and prosperity. Ultimately, learning languages brings the world closer together and promotes national security and world peace, since speaking to people in their language touches them directly. Thus, learning languages can serve as a tool of civilizational dialogue and a key to peace and conflict prevention.

\section{Some Historical and Contemporary Examples of the Utility of Multilingualism in Civilizational Dialogue}

According to Vigdis Finnbogadóttir (2001), "all languages are to be regarded as the heritage of humanity, essential not only for access to knowledge, but also for the development of understanding amongst peoples and for the dialogue for peace" (p. 19). We need to foster future generations who can help to create a better and more peaceful world through civilizational dialogue and respect. Therefore, our education systems must be reformed to prepare students who are cross-culturally competent and culturally and linguistically skilled; a key part of this will be improving language teaching, and a key part of that will be overcoming negative attitudes towards a particular language. An example is the misconceptions about Arabic words mentioned above. One study performed in 2007 explored the attitudes of American and international students in the United States regarding teaching/learning Arabic as a foreign language in the "post-9/11 era." The results showed that most international students had positive attitudes towards the Arabic language and culture, but most American students had negative attitudes (Taha, 2007).

Arabs cannot demonstrate the importance of the Arabic language unless they learn other languages. They have to initiate dialogue with those who lack knowledge of their language and culture. It is their responsibility to address the most common stereotypes and overcome negative attitudes. We cannot change the world unless we change ourselves: we have to think globally and change education systems accordingly. When we teach languages, we have to focus on the development of communicative competence to promote effective 
communication. This kind of change facilitates meaningful dialogue to resolve disagreements, whereas lack of knowledge about foreign languages and cultures jeopardizes our own language and religion. Muslims always blame Western media for portraying a negative image of Islam and criticize their ignorance of the meanings of Arabic words. And indeed, many Westerners acknowledge their lack of expertise in Arabic and Asian languages.

There is a burden of responsibility on native speakers of any language. For example, if the Western media is ignorant of the power of the Arabic language and lacks proficiency in it, Arabs must take responsibility for explaining the meanings of words that have been distorted. However, they cannot take on this responsibility successfully unless they themselves have a high degree of proficiency in both their own language and foreign languages so that they can deal competently with misunderstandings and misconceptions. Thus, the demand for multilingual Muslim scholars has increased. There are inspiring examples of Muslim scholars who were versed in many foreign languages. For example, Dr. Muhammad Hamidullah was a great scholar who spoke 22 languages (Thai was the last language he learnt, at the age of 84). He wrote books in several languages, including French, German, English, Arabic, Turkish, Persian, and Urdu. He also translated the Quran into French, English, and German.

Another example is Sheikh Ahmed Hoosen Deedat, who delivered lectures all over the world, and engaged in global dialogue in many different languages. Adnan Okta, known under his pen name of Harun Yahya, is yet another example, and has written several books on the fundamental beliefs of Islam, which have been translated into 72 languages with the help of a team of translators from various countries. These helpers allowed Yahya to express his message in the languages of countless people worldwide, supported by various communication technologies: books, videos, and the internet, as well as conferences.

Knowledge of foreign languages should not be esoteric for scholars. Everyone should be expected to speak at least two languages, in order to participate in intercultural dialogue and avert future strife. Multilingualism has the capacity to create dialogue between civilizations because speaking with people in their own language is a way of showing them respect and creating an atmosphere of openness, understanding, and moderation. Knowledge of foreign languages has ipso facto become a religious, political, social, and economic necessity in a 
globalized world, as covered above. Thus, bearing in mind the importance of peaceful dialogue, we must take advantage of new communication technologies to achieve such knowledge, in all the world's languages. New technology has opened the doors of the world; multilingualism can go further and open closed hearts. Kind words, in many languages, can create peace among nations and peace of mind.

\section{Research Methodology}

This study presents the results of a survey questionnaire intended to examine non-Westerners' points of view regarding the relationship between multilingualism and civilizational dialogue.

\section{Participants}

The questionnaire collected data randomly from non-Western graduate students in English-speaking nations based on their experiences to investigate how civilizational dialogue and mutual understanding can be created by fostering proficiency in more than one language. A total of 159 male (59.62\%) and female $(40.38 \%)$ participants were included in the study; survey participants were studying in Canada ( $n=53$ ), the United States ( $n=54)$, and the United Kingdom $(n=52)$. The participants were from different linguistic backgrounds, and many had advanced levels of foreign language proficiency. They were randomly selected as a sample to measure their opinions on the relationship between multilingualism and civilizational dialogue. The participants' age was between 18$29(13.46 \%), 30-44(21.15 \%), 45-60(32.69 \%)$, and > $60(32.69 \%)$ years old. The majority of the participants $(66.03 \%)$ had earned a bachelor's degree as their highest degree and were studying at universities and schools, followed by participants who held a master's degree (25.78\%) and a doctoral degree $(8.17 \%)$ and were studying at universities. A total of $55.97 \%$ spoke more than one language. 


\section{Instrument and Procedure}

The questionnaire was administered to the respondents to collect information about their experiences with and opinions on the relationship between multilingualism and civilizational dialogue. There were a total of 10 questions measuring opinions about the importance of multiple language acquisition in achieving global understanding and communication.

The first three questions related to the respondents' native language, their level of education, and the languages they spoke. The second three questions related to their opinions about the importance of multilingualism in civilizational dialogue and whether political and religious clashes result from cultural differences in the understanding of some words. The last four questions were related to their experiences with civilizational dialogue and what Islam means to them-as "Islam" is one of the most widespread misunderstood terms and designates a religion and civilization that has come into complex dialogue and conflict with the West-as well as their opinions on the relationship between multilingualism and civilizational dialogue.

\section{Data Analysis}

The data collected were statistically analyzed to better understand the opinions of the participants on the relationship between multilingualism and civilizational dialogue.

\section{Results}

Response rates to the survey were 54 in the United States samples and 105 in the Canadian and United Kingdom sample. When asked to indicate what, according to their experience. promotes civilizational dialogue, multilingualism or monolingualism, 83.33\% of the American respondents said "multilingualism"; and $16.67 \%$ "monolingualism"; similarly, $81 \%$ of the Canadian and British respondents said "multilingualism" and 19\% "monolingualism" (Fig. 5). This high 
percentage of agreements on multilingualism indicates the importance of multilingualism in promoting civilizational dialogue.

Q4 Based on your experience, indicate which of the following promotes civilizational dialogue.

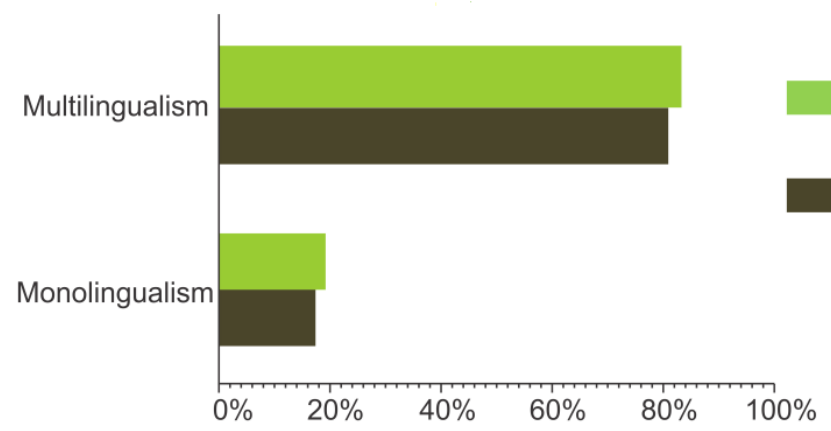

American respondents

(Answered: 54; Skipped: 0)

Canadian and British respondents (Answered: 105; Skipped: 0)

Fig. 5. Response to question on promotion of civilizational dialogue

When asked to rate how important they think multilingualism is in promoting civilizational dialogue on a Likert-type scale of 1 (extremely unimportant) to 7 (extremely important), 3.70\% of American respondents gave a response of 1 and $20.37 \%$, a response of 7 , whereas $1 \%$ of Canadian and British respondents gave a 1 and $18 \%$, a response of 7 (Fig. 6). Thus, multilingualism is the most highly ranked and rated.

Q5 On a scale of 1 to 7 , with one being extremely unimportant and 7 being extremely important, please rate how important you think multilingualism (multiple language acquisition) is in promoting civilizational dialogue.

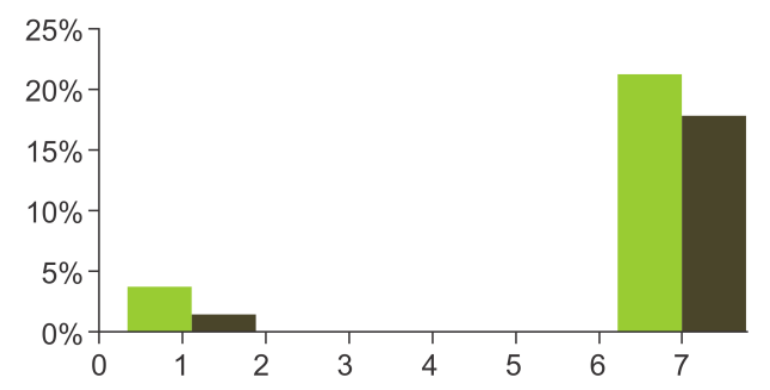

American respondents

(Answered: 54; Skipped: 0)

Canadian and British respondents (Answered: 105; Skipped: 0)

Fig. 6. Response to question on importance of multilingualism 
When asked if political and religious clashes stem from cultural differences in the understanding of words like jihad, terrorism, peace, democracy, liberty, etc., $46.30 \%$ of American respondents indicated yes, $18.52 \%$ no, and $35.19 \%$ indicated that they didn't know. The figures for Canadian and British respondents were $50 \%, 17.14 \%$, and $31.43 \%$, respectively (Fig. 7 ). The responses are thus fairly split, but a plurality of participants expected cultural differences to be the reasons for political and religious clashes.

Q6 It has been argued that political and religious clashes stem from the cultural differences in the meaning of the words used such as Jihad, terrorism, peace, democracy, liberty....etc.

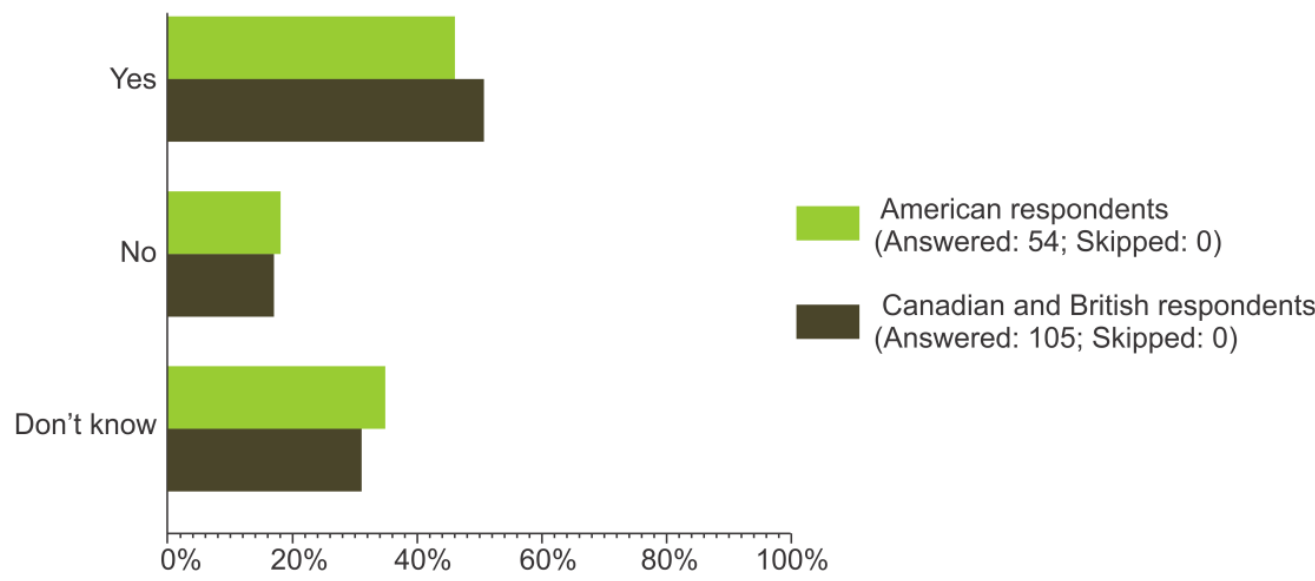

Fig. 7. Response to question on cultural differences

Around $20 \%$ of American respondents and around $25 \%$ of Canadian and British respondents indicated that they had previously engaged in civilizational dialogue with persons with different native language, religious beliefs, or political opinions (Fig. 8). This high percentage supplies evidence of the impact of learning multiple foreign languages on civilizational dialogue. 


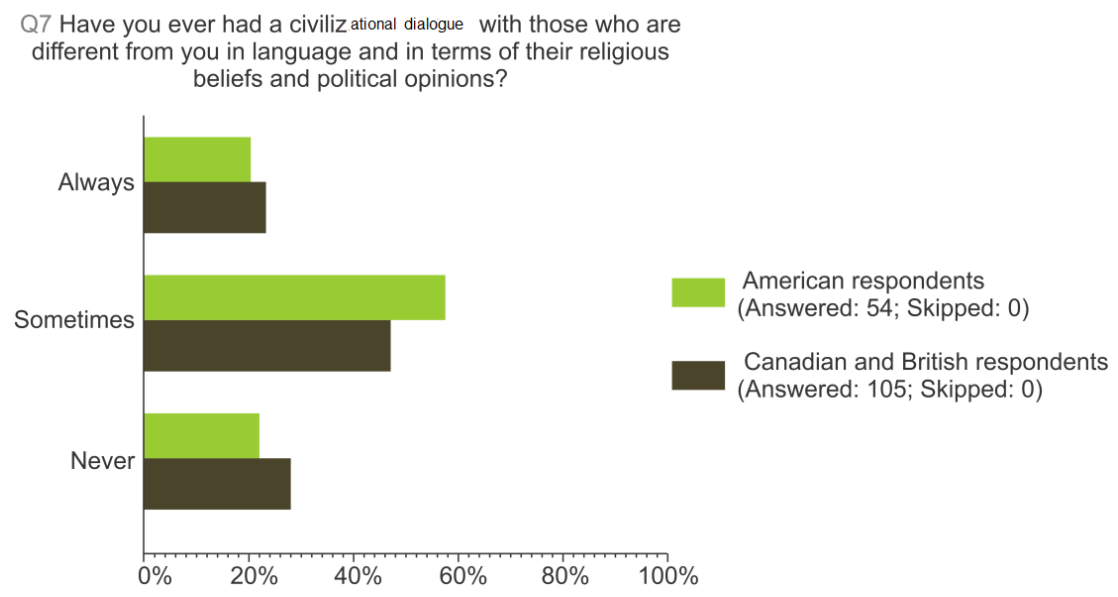

\section{Fig. 8. Response to question on civilizational dialogue with persons of other language/religion/political opinions}

When asked what Islam means to them, $29.63 \%$ of American respondents said "terrorism" and 70.37\% said "peace." Of Canadian and British respondents, $47.62 \%$ said "terrorism" and 52.38\% "peace" (Fig. 9). Islam means peace to a high level of participants who speak more than one language.

Q8 These days, one of the widespread misconceptions is that concerning the concept of Islam. What does Islam mean to you?

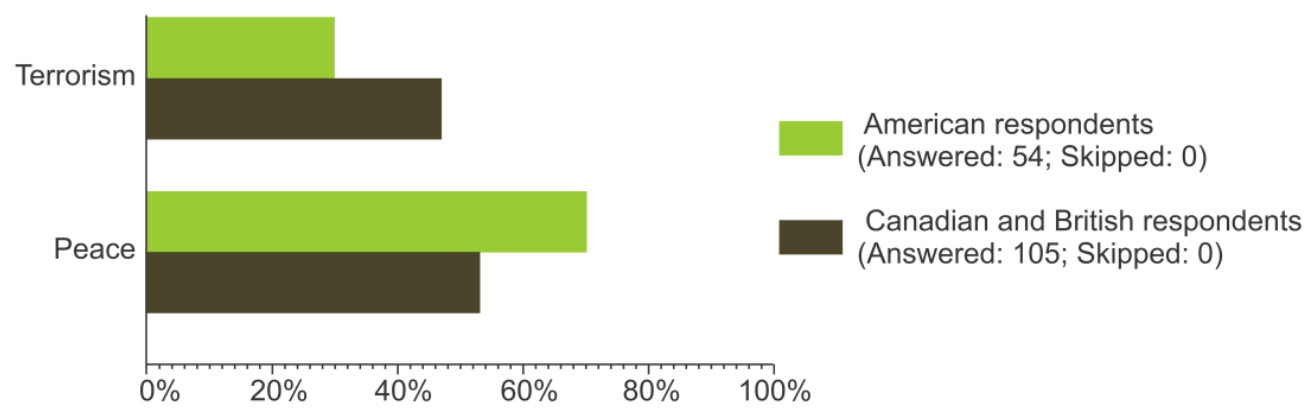

Fig. 9. Response to question on concept of Islam 
When asked where they got this meaning from, $20.37 \%$ of American respondents mentioned non-Western websites and media and $79.63 \%$ said Western websites and media. Of Canadian and British respondents, 33.33\% mentioned nonWestern websites and media and $66.67 \%$ Western websites and media (Fig. 10).

Q9 Where did you get this meaning from?

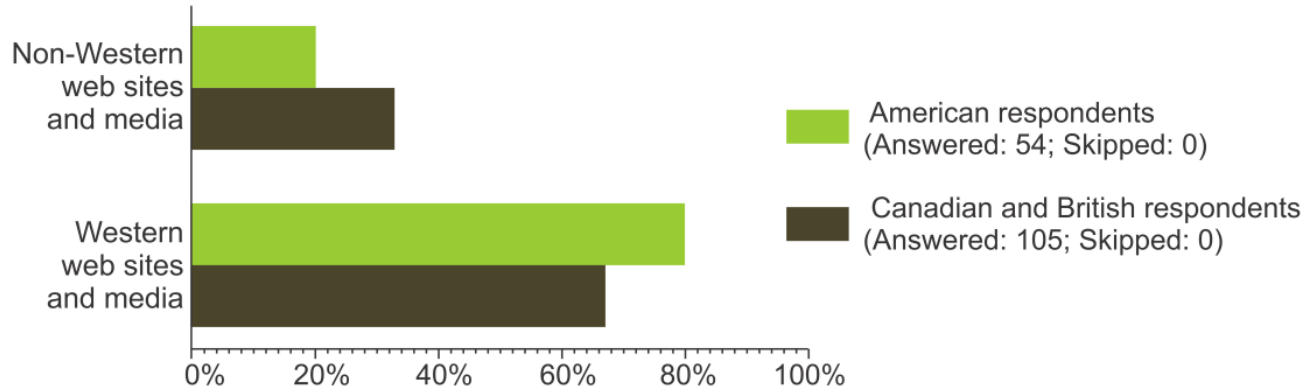

Fig. 10. Response to question on source for meaning of Islam

It is worth noting that the majority of the respondents consulted Western websites and media because of their ability of knowing other languages.

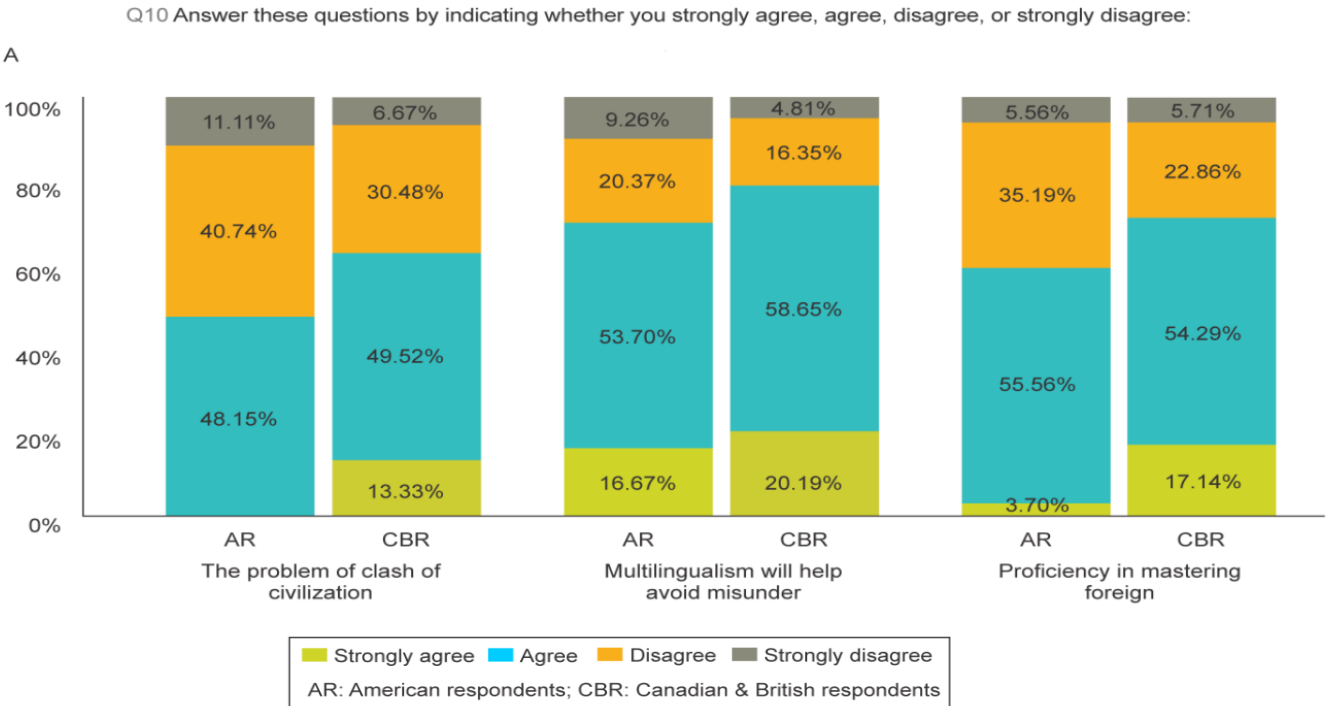

Fig. 11a. Response to level of agreement on importance of multilingualism 


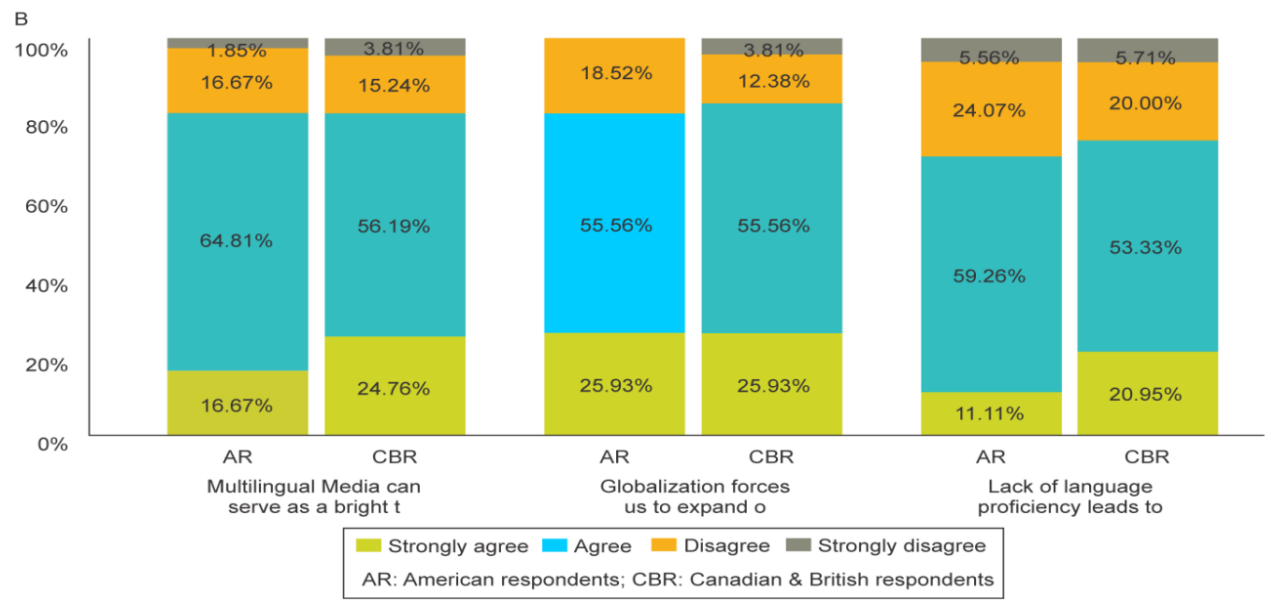

Fig. $11 \mathrm{~b}$. Response to level of agreement on importance of multilingualism

When asked to indicate their level of agreement with each of a list of statements emphasizing the importance of multilingualism in promoting civilizational dialogue, the participants indicated high agreement on the whole (Fig. 11 a, b).

\section{Discussion}

In this study, a significant difference was noted between participants' experiences using one language and their experiences using other languages in their dialogues. Participants who know more than one language agreed that knowing more than one language and speaking with people in their own language can create civilizational dialogue and mutual understanding more than being monolingual can. The majority of the participants had engaged in civilizational dialogue with people of a different native language, religious faith, or political opinion; and the majority spoke more than one language. The participants agreed that political and religious clashes can stem from cultural differences in the understanding of words such as jihad, terrorism, peace, democracy, liberty, and others. These results indicate that people speaking more than one language are more likely to have a civilizational dialogue and less likely to face misconceptions.

Further, those who related Islam to terrorism took this meaning from non-Western websites and media that lack deeper knowledge of the Arabic 
language and the real meaning of Islam. However, those who related Islam to peace took this meaning from Western websites because of their ability to speak other languages.

The results of this survey thus help support the argument of this study that the problem of clash of civilizations can be solved through multilingualism, which promotes inter-civilizational dialogue, and that proficiency in foreign languages is a tool for facing and averting global conflicts. These results bring us to the conclusion that lack of language proficiency leads to misconceptions and clash of civilizations. People like these respondents will play a pivotal role in fostering global dialogue.

\section{Conclusions}

Foreign language proficiency and intercultural dialogue are the wings of the bird of peace. Having both, we will have secured the best and most powerful tool for successful communication in the world. This study confirms the idea that multilingualism is a solution rather than a problem. Of the participants in this study, a total of $55.97 \%$ spoke more than one language, and the majority had engaged in civilizational dialogue with people of a different native language, religious faith, or political opinion. In this regard, their experiences of civilizational dialogue demonstrated the value of multilingualism in solving the problem of clash of civilizations. The results also showed that cultural differences in the understanding of words such as jihad, terrorism, and peace may exacerbate the problem of clash of civilizations.

The absence of communication skills means the seeds of dialogue cannot grow. Familiarity with foreign languages per se is not enough for productive communication; rather, we must have a level of proficiency in foreign cultures, across various academic specialties, and the language that appertains to them: the special terminology of religious, history, economics, politics, and culture.

The task is enormous and complex; yet multilingualism is the best way of underpinning civilizational dialogue. Therefore, in addition to better language skills on the whole, we need more academic research in different languages on different cultures, oriented towards the global goal of promoting academic "dialogue between civilizations." Research into the scientific and linguistic 
miracles of the Qur'an, for instance, must be conducted in multiple languages in order to unravel and unpack the deeper meanings of Qur'anic language from the perspectives of both believers and nonbelievers working from within various linguistic thought-worlds. The Qur'an is considered miraculous by Muslims for the unique style and presentation it gives to the Arabic language due to its matchless eloquence and unique literary form.

Further, polyglot centers of research on multilingualism should be established for scholars in these fields to share ideas with one another, fostering global academic dialogue. The first Asian polyglot center has been established in Iran by a young Iranian man named Ali Pirhani, who speaks 19 languages.

In this study, I have just touched upon a small number of the effects of multilingualism on civilizational dialogue in the attempt to increase awareness of the importance of multiple language acquisition. I hope this will provoke us to further study of how to open up new horizons for civilizational dialogue based on multilingualism and mutual cultural knowledge.

\section{References}

Abu Bakr, T. (2004). The lack of understanding between Arabs and the West. Common Ground Series.

Afroz, A. (2004). Overcoming misunderstandings: Understanding jihad. Mt. Lewis, NSW: al-Ghazzali Centre.

Bakar, Osman (2001). Inter-civilizational dialogue: Theory and practice in Islam. In Mitsuo, N. et al. (Eds.), Islam and civil society in Southeast Asia (pp. 146-176). Singapore: Institute of Southeast Asian Studies.

Blommaert, J., \& Spotti, M. (2012). Endangering multilingualism. In J. Blommaert, S. Leppäinen, P. Pahta, \& T. Räisänen (Eds.), Dangerous Multilingualism. London, UK: Palgrave Macmillan.

Buda, M. (2010, March). L'application du multilinguisme dans I'Union européenne-un problème sans issue? Social Sciences Research Network. Retrieved from ssrn.com/abstract $=2233903$.

Cenoz, J. (1998). Beyond bilingualism: Multilingualism and multilingual education. Bristol, UK: Multilingual Matters. 
Clyne, M. (2007). Multilingualism. In F. Coulmas (Ed), The handbook of sociolinguistics. Hoboken, NJ: Blackwell Publishing.

Committee for Economic Development. (2006). Education for global leadership: The importance of international studies and foreign language education for U.S. economic and national security. Washington, D.C.: Committee for Economic Development.

Dash, N. S. (2008). Context and contextual word meaning. SKASE Journal of Theoretical Linguistics, 5(2), 21-31.

De Angelis, G., \& Dewaele, J.-M. (2009). The development of psycholinguistic research on cross linguistic influence. In L. Aronin \& B. Hufeisen (Eds.), The exploration of multilingualism: Development of research on L3, multilingualism and multiple language acquisition (pp. 63-77). Amsterdam: John Benjamins.

Edwards, J. (1994). Multilingualism. London: Routledge.

Finnbogadóttir, V. (2001, July 31). Dialogue among civilizations: The political aspects of the dialogue of civilizations. Speech given at United Nations University, Tokyo.

Hulstrand, J. (2008). Building a fluent workforce. Retrieved from http://www.nafsa.org/_file/_/ie_sepoct08_fl uentwork.pdf.

Kachru, Y. (1989). Code-mixing, style repertoire and language variation: English in Hindu poetic creativity. World Englishes, 8(3), 311-319.

Katharina, Crepaz. (2009). The EU language policies: Between multilingualism, minority language protection and English as the new Lingua Franca (Master's Thesis).

Kymlicka, W. (2001). Politics in the vernacular. Oxford, UK: Oxford University Press.

Kytölä, S. (2013). Multilingual language use and metapragmatic reflexivity in Finnish internet football forums. A study in the sociolinguistics of globalization. Unpublished doctoral dissertation, University of Jyväskylä.

Mir, A. (2010). Conclusions of the $3^{\text {rd }}$ global seminar on linguistic diversity, globalization and development. Retrieved from http://www15.gencat.net/pres_casa/llengues/uploads/newsletter/conclusi ons_GSAlexandria_LF_EN_revisat.pdf. 
Ngubane, B. S. (2003, June 12). Future of multilingualism in South Africa: From policy to practice. Keynote address given at the National Multilingualism Conference, Benoni, South Africa.

Orban, L. (2007). Message to language teachers at the REAL Seminar. Retrieved from

http://www.ciep.fr/en/expert_langues/etrangeres/docs/2007/septembre/ message_Orban.pdf.

Orban, L. (2008). Towards a comprehensive strategy for multilingualism. Retrieved from http://www.programmallp.it/lkmw_file/LLP///in_evidenza/EN_speech_Hell enic_Parliament.pdf

Orban, L. (2009a). Multilingualism - A policy for uniting European speech. London School of Economics. Retrieved from http://ec.europa.eu/commission_barroso/orban/news/docs/speeches/090 519_London_School_Economics/London_School_Economics_May_2009_e n.pdf.

Orban, L. (2009b). Multilingualism - a bridge to mutual understanding. Speech, Conference on Multilingualism, Belgium.

Peal, E., \& Lambert, W. (1962). The relation of bilingualism to intelligence. Psychological Monographs, 76, 1-23.

Scarino, A., \& Crichton, J. (2007). 'Why the intercultural matters to languages teaching and learning: An orientation to the ILTLP programme." ILTLP Discussion Paper 1. Retrieved from www.iltlp.unisa.edu.au/doclibpaper /iltlp_paper1.pdf.

Stolarickô, K., \& Florida, R. (2006). Creativity, connections, and innovation: A study of linkages in the Montréal region. Environment and Planning $A$, 38(10), 1799-1817.

Taha, T. (2007). Arabic as a "critical-need" foreign language in the post-9/11 era: A study of students' attitudes and motivation. Journal of Instructional Psychology, 34(3), 150-160.

Tokuhama-Espinosa, T. (2008). Living languages: Multilingualism across the lifespan. Santa Barbara, CA: Praeger.

UNESCO. (2009). UNESCO world report: Investing in cultural diversity and intercultural dialogue. Paris: UNESCO. 


\author{
Nawal A Al-Fattah \\ Taif universitetas, Saudo Arabija \\ a.f_nanni@yahoo.com
}

\title{
DAUGIAKALBĖS KOMPETENCIJOS SVARBA: NUO KONFLIKTU TARP TAUTU LINK CIVILIZACIJU DIALOGO
}

Santrauka. Šioje žodžiu karu eroje daugiakalbès kompetencijos igijimas ir kultūrinis sąmoningumas gali padeti išspręsti nesusipratimus ir konfliktus tarp civilizaciju. Kalbos barjerai gali būti nepavykusios komunikacijos priežastimi, o daugiakalbès visuomenès sukūrimas galbūt padètu užkirsti kelia nesusipratimams, kylantiems dèl nepakankamos kitos kalbos kompetencijos ir kitokio mąstymo būdo. Tyrimas analizuoja daugiakalbystès nauda civilizacijos dialogui ir akcentuoja žiniasklaidos panaudojimo svarba, skatinant komunikacija tarp tautu. Nagrinèjamas ryšys tarp daugiakalbystès ir konstruktyvaus dialogo, siekiant irodyti, kad daugiakalbystè nèra problema, kurią reikia išspręsti. Pateikiama keletas istoriniu ir šiu dienu pavyzdžiu, iliustruojančiu kalbos svarba civilizaciju dialogui ir irodančiu teigiama daugiakalbystès itaką. Šie pavyzdžiai rodo, kad individualios daugiakalbystès augimas, t. y. augantis skaičius keliomis kalbomis kalbančiu žmoniu gali turèti teigiama poveiki visuomenei. Atlikta 159 respondentu anketinè apklausa rodo, kad daugumos respondentu nuomone, daugiakalbystè skatina civilizaciju dialoga labiau nei tik vienos kalbos mokejimas. Respondentai taip pat sutinka, kad daugelis politiniu ir religiniu konfliktu kyla dèl kultūriniu skirtumu, salygojančiu klaidingą kai kuriu sąvoku supratima.

Pagrindinès sąvokos: civilizacija, daugiakalbystè, dialogas, globalizacija, konfliktas. 